\title{
Avisacja, czyli ptaki Józefa Mackiewicza
}

Adam Fitas

TEKSTY DRUGIE 2018, NR 2, S. 221-234

DOI: $10.18318 /$ td.2018.2.14

Gdyby jednak wiedzieć mogły [dzikie zwierzęta], co wróg-człowiek i jakimi sztuczkami magicznymi potrafi z [...] lasem wyrabiać stanęłaby dęba sierść na sarnach i futro na drapieżnikach,

i ze zdziwienia pióra na ptakach. Nie-sły-cha-ne!"

\section{1.}

Już pobieżny ogląd tematu podpowiada niedwuznacznie, że motyw, który chcemy poddać literaturoznawczej analizie, należy w tym przypadku do jednego z obrazów kluczowych i dla biografii, i dla twórczości interesującego nas pisarza. Nieprzypadkowo przecież Józef Mackiewicz został nazwany w monografii Włodzimierza Boleckiego „ptasznikiem z Wilna” (notabene motto książki jest

\footnotetext{
Adam Fitas - dr hab., profesor nadzwyczajny w Katedrze Teorii i Antropologii Literatury KUL.

Zainteresowania: twórczość Józefa Mackiewicza, Karola Ludwika Konińskiego, genologia polskiej prozy współczesnej, a zwłaszcza problematyka literatury dokumentu osobistego. Ostatnia książka: Zamiast eposu. Rzecz o „Dziennikach”Zofii Nałkowskiej (2011). Kontakt: fitamka@ kul.pl
}

1 J. Mackiewicz Kto u nas kupuje majq̨tki po 43 zł za ha?!, "Słowo” 1937 nr 5, w: tegoż Okna zatkane szmatami, Wydawnictwo Kontra, Londyn 2012, s. $15-16$. 
cytatem z tekstu prozaika, poświęconego skrzydlatej braci)2 ${ }^{2}$.Ta zgrabna i szeroko dziś w literaturze przedmiotu zadomowiona antonomazja przylega ściśle zarówno do dziecięcych, młodzieńczych, a nawet studenckich fascynacji przyszłego autora Kontry światem przyrody, a zwłaszcza ptakami, jak również do przekrojów rzeczywistości przedstawionych i w jego międzywojennej publicystyce, i - w jednocześnie tworzonych bądź późniejszych - fabułach nowelistycznych czy powieściowych.

Każdy czytelnik Mackiewicza bez trudu i bez potrzeby żmudnego liczenia motywów zauważy od razu, że wyobraźnia pisarza jest szczególnie wrażliwa na naturalne otocznie człowieka, a szczególnie na ptaki. Im samym poświęcił on kilka swoich tekstów publicystycznych i autobiograficznych. Przykładowo, tuż przed II wojną, w sierpniu 1939 roku, pisał o Odwiecznej zagadce ptasiego fenomenu ${ }^{3}$, nieco wcześniej dzielił się refleksjami o oswojonym przez siebie kruku w quasi-opowiadaniu Krakaś, a jeszcze dawniej wspominał o pierwszych fascynacjach związanych z obserwowaniem, łowieniem i hodowaniem ptaków, czyli o pasjach, które wyrosły z lektury Prirody Modesta Nikolaevicha Bogdanowa czy Życia zwierząt Alfreda Brehma. Otrzymawszy tę drugą książkę na gwiazdkę, wyznawał:

W przyległym pokoju, w niewielkiej klatce spały już, schowawszy główki pod skrzydełkiem, moje ukochane ptaki. Byłem zamiłowanym przyrodnikiem od dzieciństwa. ${ }^{5}$

$\mathrm{Ba}$, pisarz miał za sobą nawet nie lada odkrycie ornitologiczne, kiedy to w ramach studiów przyrodniczych na Uniwersytecie Warszawskim odbył podróż badawczą do Puszczy Białowieskiej, w której wypatrzył i upolował

2 Zob. W. Bolecki Ptasznikz Wilna. O Józefie Mackiewiczu. \{Zarys monograficzny), wyd. 2 uzupełnione, poprawione i rozszerzone, Wydawnictwo Arkana, Kraków 2007.

3 J. Mackiewicz Odwieczna zagadka ptasiego fenomenu, "Słowo" 1939 nr 217 (9 sierpnia), w: tegoż Nudis verbis, Wydawnictwo Kontra, Londyn 2017, s. 172-178. Z tego też artykułu pochodzi motto do książki Boleckiego (s. 172): „Na niebie, w powietrzu, pomiędzy obłoki, ponad lasy, ku horyzontom ciągną ptaki. Ciągną jesienią, ciągną wiosną. Bywa, że słychać szum ich skrzydeł, bywa, że widać tylko dalekie punkciki, że dochodzą z góry ich wołania tęskne. I człowiek tęskni z nimi razem, i wzdycha do czegoś, co pobudza jego fantazję, wyzwala marzenia. Chciałby wiedzieć". J. Mackiewicz Krakaś, "Słowo” 1937 nr 336 (5 grudnia), w: tegoż Okna zatkane szmatami, s. 219-224.

5 J. Mackiewicz Alfred Brehm, "Słowo" $1934 \mathrm{nr} 325$ (27 listopada), w: tegoż Bulbin z jednosielca, Wydawnictwo Kontra, Londyn 2017, s. 326. Na temat Prirody Bogdanowa zob. w tym samym tomie wspomnienie Ptaki w klatce, s. 331-335 (pierwodruk: „Słowo” 1935 nr 21, 22 stycznia). 
niezwykle rzadko tu spotykanego dzięcioła trójpalczastego. Przy okazji wspominania po latach tego epizodu, powiadał $\mathrm{w}$ dygresji:

Pisarzem jestem tylko z zawodu, a z wykształcenia jestem przyrodnikiem, zoologiem, zoogeografem, ekologiem. ${ }^{6}$

By skończyć ten biograficzny wątek, zaznaczę tylko, że ze znanych mi pisarzy polskich Józef Mackiewicz jest - oprócz Czesława Miłosza - jednym z najlepszych znawców przyrody dawnego Wielkiego Księstwa Litewskiego i zdecydowanie najznakomitszym znawcą ptaków.

Naturalnie teksty przywołane przed chwilą, związane głównie z dyskursywnym trybem opisu tematu (są to głównie artykuły wspomnieniowe), nie wyczerpują ptasiej problematyki w jego twórczości, ale stanowią dla niej pomocny kontekst interpretacyjny. Najbardziej bowiem interesujące w ujęciu przez pisarza zagadnienia jest wprzęgnięcie przez niego całego „ptasiego fenomenu" w ideowy kosmos znaczeń i nadanie mu w tym świecie ważkiej funkcji artystycznej. Wyprzedzając nieco obserwacje, powiedzieć można ogólnie, że ptaki są w przypadku pisarstwa autora Drogi donikąd świetnym pars pro toto przyrody, symbolicznym znakiem funkcji, jakie pełni w filozoficznym credo Mackiewicza cała natura rozumiana jako swoisty ślad przyrodzonej, czyli - w aksjologii pisarza - najbardziej obiektywnej prawdy7.

\section{2.}

Już z tego krótkiego i bardzo szkicowego anonsu tematu można się łatwo rozeznać, że na napisanie wyczerpującej rozprawy o ptakach Mackiewicza potrzeba znacznie więcej miejsca niż artykuł, ba, sądzę, że materiału byłoby dość i na monografię. Dlatego zaprezentuję tutaj nie próbę całościowej syntezy problematyki, ale jej, jak mi się wydaje, instruktywną egzemplifikację. Skupię się mianowicie na skrótowej analizie jednej, ale reprezentatywnej dla twórczości Józefa Mackiewicza fabuły, w której spotykają się podstawowe

6 J. Mackiewicz „Ech, puszcza...”, „Russkaja Mysl” Paryż 1962 nry 1809, 1810 (8 i 10 kwietnia), w: tegoż Tajemnica żółtej willi i inne opowiadania, Londyn 2015, s. 76. Artykuł Mackiewicza, w pierwodruku po rosyjsku, przetłumaczyła Nina Karsov.

7 O znaczeniach przyrody dla pisarza piszę szerzej i w trybie bardziej ogólnym w szkicu Od przyrody-dokumentu do „przestrzeni Bożej". Natura w prozie Józefa Mackiewicza, w: Horyzont religijny polskiej literatury emigracyjnej, red. P. Panas, RW KUL, Lublin 2013. 
funkcje ptaków pojawiające się także w innych jego tekstach publicystycznych, reportażowych i fikcjonalnych.

\section{3.}

Nowela Faux-pas ciotki Pafci zawiera w sobie wiele cech charakterystycznych dla całej prozy narracyjnej Mackiewicza. Zasygnalizujmy te najbardziej widoczne: w rzeczywistości przedstawionej pojawiają się fakty historyczne (w tym zwłaszcza z historii politycznej) i zbeletryzowane zdarzenia z biografii autora, a ideowy sens opowieści wyraża się w kluczowej dla światopoglądu pisarza opozycji między starymi a nowymi czasami. Sygnalizowana jest ona już w pierwszym zdaniu utworu:

W chwili obecnej ciotka małego Henryka, gdyby żyła, liczyłaby dokładnie lat 86. Ale nie żyje już od roku 1940. Weszła więc i tak bardzo głęboko $\mathrm{w}$ wiek XX, do którego nigdy nie należała. ${ }^{8}(7)$

Powieści i opowiadania „ptasznika z Wilna”, dorzućmy jeszcze jedną stałą cechę pisarstwa Mackiewicza, nie należą do fabuł polifonicznych, w których bardzo trudno odczytać ideowy zamysł autorski, rozpisany wówczas zazwyczaj na wiele równorzędnych aksjologicznie postaw uosabianych przez postaci. Wręcz przeciwnie: są to zasadniczo utwory z wyraźną i dobitnie wyeksplikowaną tezą pisarską. Nie znaczy to jednak, że mamy do czynienia z literacką publicystyką, choć i takie opinie o autorze Kontry były wypowiadane. Jego małe i duże narracje, choć jasno wskazują kierunek interpretacji założony przez autora, żywią się bowiem sugestywnym, artystycznym rozegraniem idei. Te ostatnie zostają plastycznie zobrazowane na przykładach biografii ludzkich, które wchodzą ze sobą w niezwykłe, ale prawdopodobne relacje (często mające swoje autentyczne pierwowzory) i razem ewokują intrygujące i wieloaspektowe sploty ludzkich losów. Przy czym - co nas interesuje tu najbardziej - odbywa się to w stałym, choć mniej bądź bardziej widocznym nawiązaniu do świata natury.

Otóż tytułowa ciocia, o której przeczytaliśmy przed chwilą, nabiera życia w noweli i konkretyzuje się jako plastyczna postać „z krwi i kości” poprzez

8 J. Mackiewicz Faux-pas ciotki Pafci, w: tegoż Ściagaczki z szuflady Pana Boga, posł. B. Toporska, Wydawnictwo Kontra, Londyn 2007, s. 7-32. Cyfra przy cytatach z noweli oznacza numer strony. Pierwodruk noweli: „Kultura” $1952 \mathrm{nr} 1$ (51). 
stopniowe przyjmowanie ptasiego wyglądu. Proces tej metamorfozy zapowiada już na początku opowieści sam narrator, prezentując powierzchowność bohaterki i antycypując dalsze części fabuły:

stara, z dużą broszką bursztynową pod brodą, i parasolem, którego rączka zakończona była kształtem głowy ptasiej o drapieżnym dziobie. Z czasem twarz ciotki nabrała ostrości rysów, a nos się wydłużył i upodobnił do tej rączki parasola [...]. (7)

Kolejne gafy cioci, które stanowią osnowę fabuły noweli, polegają - najogólniej rzecz ujmując - na przeciwstawieniu szacunku dla każdego człowieka, bez względu na jego narodowość czy wyznanie, postawie, w której odróżnia się swoją nację (w domyśle: lepszą) od innej, naturalnie gorszej. Nietrudno zorientować się, że Mackiewicz rozpisuje w ten sposób rodzące się w łonie wielonarodowej kultury byłego Wielkiego Księstwa Litewskiego separatyzmy poszczególnych grup etnicznych oraz dochodzący do głosu komunizm. Dla cioci Pafci drogi będzie zatem i polski rodak z sąsiedztwa, i ucząca dzieci kochana Fräulain Klara z Niemiec, i zaprzyjaźniony z rodziną Rosjanin, Iwan Mikołajewicz, za mąż zaś wyjdzie za Litwina jeszcze w czasach, gdy „wszyscy mieszkańcy b. W. Księstwa Litewskiego przezywali siebie Litwinami".

Tłem dla jej niedzisiejszych manier pozostają przy tym nie tylko zmiany polityczne, o których wspomnieliśmy przed chwilą, ale także polskie wychowanie patriotyczne, w którym zarówno niemieckie (czy pruskie), jak i rosyjskie dziedzictwo i mowa traktowane są en bloc jako wrogie, a w każdym razie zdecydowanie obce.

Ze zderzenia tych postaw rodzą się owe tytułowe faux pas, które ciocia popełnia seriami. A to nakazując dzieciom przeproszenie niemieckiej bony, a to darując bratankowi rosyjską książeczkę dla dzieci Tietuszka Piko czy pruską czapkę, a to wreszcie, pamiętając w kolejnym prezencie, którym są dwa kanarki, o rosyjskim koledze bratanka, dla którego przeznaczony jest drugi z ptaków. Kontrastem dla jej naturalnych w istocie zachowań jest atmosfera patriotyczna domu, w którym Radziwiłłowie to - za Sienkiewiczem - jednoznaczni zdrajcy, w którym Tierleben Brehma, ponieważ niemieckie, ustępuje miejsca czytance o pokonaniu Krzyżaków pod Grunwaldem i w którym odbywają się patriotyczne kinderbale bez niemile widzianych dzieci rosyjskich sąsiadów, na koniec - w którym wypowiada się brzmiące dla cioci Pafci jednoznacznie bluźnierczo słowa o Polsce jako Chrystusie narodów. 
Epizody te opatrywane są przy tym niejednokrotnie subtelnymi, przy pierwszej lekturze ledwo zauważalnymi, aluzjami do ptaków. Oto w momencie, gdy matka chłopca zastanawia się, czy istotnie nie lepsza będzie dla dziecka lektura o Grunwaldzie niż dzieło Brehma, ciocia wtrąca, że „toż przecie o ptaszkach", a w chwili, gdy chłopiec zmuszony jest podczas balu do wyproszenia swojego najlepszego, ale - niestety - rosyjskiego kolegi, z którym zgłębiał tajniki łowienia i hodowli ptaków, z ust narratora pada taki oto komentarz:

O ptakach ani zwierzętach nie mówili. Tomy „Tierleben” stały na półce i świeciły stamtąd złotymi literami na grzbietach. Przez okno dochodził świergot i duszny zapach przekwitającej czeremchy. (24)

Nieco wcześniej natomiast, gdy nasz młody bohater Henryk, zafascynowany książką podsuniętą przez nauczyciela (notabene pod tytułem Priroda autorstwa Iwanowa9) biegnie do domu, aby zobaczyć upragnionego gila kupionego przez matkę, z łatwością bagatelizuje toczącą się obok rozmowę między kucharką a praczką o tym, czy Żyd to człowiek. Narrator nie omieszka zaznaczyć, że gdyby nie fascynacja ptakiem, chłopiec z pewnością włączyłby się do tej „uczonej” dysputy. Temat żydowski powraca w noweli jeszcze raz, gdy Henryk, pokłócony z rosyjskim kolegą za sprawą patriotycznego kinderbalu, odrzuca propozycję innego rówieśnika, aby pójść pod Ostrą Bramę i „Żydom czapki zrzucać z głowy”, a następnie wraca do domu i wypuszcza z klatek wszystkie hodowane przez siebie ptaki ${ }^{10}$.

9 Zmiana nazwiska z Bogdanowa na Iwanow jest tutaj detalem, który odsłania autobiograficzne i faktograficzne tło przedstawionych zdarzeń. Nowela, podobnie jak wiele innych fabuł Mackiewicza, jest bowiem przetworzoną wersją osobistych doświadczeń. Inny przykład: ze wspomnień pisarza wiemy, że książkę Bogdanowa podsunęła mu tzw. dama klasowa, czyli wychowawczyni, która obserwowała jego zainteresowania naturą (zob. .). Mackiewicz Ptaki w klatce, s. 331). W noweli zaś odbywa się to bezpośrednio po sytuacji, w której Henryk, zapatrzony w drzewo i skaczącego na nim ptaka, zapomina o toczącej się lekcji matematyki. Nauczyciel patrzy na to z dezaprobatą, ale po zajęciach pożycza młodemu przyrodnikowi książkę Iwanowa Priroda. w tym między innymi do kanarków, które ciocia Pafcia zupełnie naturalnie przynosi w darze i swojemu polskiemu krewnemu, i jego rosyjskiemu koledze, przywodzi na myśl jedną z najsłynniejszych scen z tym motywem. Mam na myśli śmierć kanarka wspominanego przez Janusza Korczaka, o którym „syn dozorcy domu orzekł, że był Żydem”, a służąca powiedziała, że nie można postawić na jego grobie krzyża, " "bo on ptak, coś bardzo niższego niż człowiek". Zob. 
Te ptasie aluzje i szczegóły podsuwane przez pisarza jako zaplecze motywacyjne postaci tworzą koloryt całej noweli i rozgrywają główny jej temat obrazowy, którym jest metamorfoza ciotki w ptaka. Decydujący moment $\mathrm{w}$ tej przemianie następuje jednak nie podczas konfrontacji z przesadnym patriotyzmem polskim czy w trakcie zderzenia z rodzącymi się antagonizmami narodowościowymi w łonie byłego Wielkiego Księstwa Litewskiego, ale podczas pierwszego zetknięcia się ciotki z bratem Henryka, Leosiem, który przystał do komunistów. Pafcia, witając go w progu, od razu zwróciła mu uwagę, aby rzucił „tych swoich żulików”, na co kuzyn zakręcił się na pięcie i odjechał. Komentarz narratora nie pozostawia wątpliwości co do przełomowego charakteru zdarzenia:

Na pozór nie zaszło nic takiego, incydent był raczej z rzędu błahych, a przecież nigdy przedtem nos ciotki nie zwisał w ten sposób nad wystającym podbródkiem, przydając twarzy wyraz krogulczy: ciotce Pafci z bursztynową broszką, a jak wielu twierdziło dotychczas, z bursztynowym sercem. (30)

Kontrast, który rysuje się w wizerunku postaci ze względu na opozycję między drapieżnym ptakiem a dobrym sercem obrazowo sygnalizuje stan ducha bohaterki w nowych czasach, a zwłaszcza w zetknięciu z totalitarną ideologią. W jednej z ostatnich scen opozycja ta zostaje przywołana jeszcze raz, gdy układająca pasjansa ciocia z krogulczym nosem przypomina sobie, patrząc na asa pik, niewinną książeczkę dla dzieci po rosyjsku: Tietuszka Piko... Naturalnie, pochodzący z XIX wieku parasol z głową drapieżnego ptaka, mimo że zniszczony, zabrała Pafcia ze sobą, gdy po załatwieniu wszystkich spraw w Wilnie udała się do Kowna, do męża Litwina.

\section{4 .}

Jak zaznaczyłem przed tym krótkim omówieniem noweli, jest ona charakterystyczna dla sposobu ujęcia przez Mackiewicza tematu ptaków i w innych jego tekstach. Poza tym, że u pisarza znającego się na tych uskrzydlonych stworzeniach jak mało który literat, ptaki przedstawiane są ze szczególną dbałością o realizm ich zwyczajów czy wyglądu, mają one - jak widać - do

J. Korczak Pamiętnik i inne pisma z getta, przyp. M. Ciesielska, posł. J. Leociak, Wydawnictwo W.A.B., Warszawa 2102, s. 14. 
spełnienia także ważną funkcję metaforyczną. Występująca w narracji animizacja czy raczej powiedzieć by należało $\mathrm{w}$ tym przypadku avisacja postaci nie ma wiele wspólnego z realizmem magicznym, ale jest obrazową i konsekwentnie sugerowaną tezą, że ludzie w pewnym czasie zaczęli zrywać swoją więź z tym, co przyrodzone ich naturze, godne dla człowieka i postanowili zaprzeczyć samym sobie. Uległość wobec schematów doktryny nadmiernego patriotyzmu, nacjonalizmów, a przede wszystkim wobec komunizmu sprawiła, że całkowicie zerwali z charakterystycznym dla człowieka, a - zdaniem Mackiewicza - obecnym w wychowaniu humanistycznym do końca XIX wieku (uosabia je w noweli tytułowa ciocia Pafcia) otwarciem na innych, poszanowaniem cudzej odrębności etc. W konsekwencji przestali być wierni własnej naturze opartej na wolności myśli i swobodzie indywidualnych przekonań.

Otóż ta wierność naturze jest w świecie pisarskim Mackiewicza wyraźnie powiązana z wrażliwością na przyrodę, pejzaż wokół i na dostrzeganie konkretnych reguł i porządków w otoczeniu. Ciocia Pafcia staje się zatem łudząco podobna do ptaka, ponieważ zdecydowanie opowiada się za tymi regułami i porządkami, w przeciwieństwie do zwyczajów, które opanowują jej wydawałoby się naturalne, bo ludzkie, sąsiedztwo. Zakończenie noweli, jeśli pojmiemy ptaki jak pars pro toto natury, żywo przypomina finał Drogi donikąd, w którym opór głównego bohatera wobec komunizmu kończy się w mateczniku puszczy, symbolicznie sygnalizującym jego opowiedzenie się, bez względu na tragiczne konsekwencje, po stronie wierności sobie, a nie pozostanie w obcęgach takiej czy innej doktryny.

Symptomatyczne, że pisarz jest zdecydowanym przeciwnikiem antropomorfizacji przyrody"1. Uważa ją, co bezpośrednio słyszymy w tekście o udomowionym kruku, Krakasiu, za świadectwo słabego wyczucia rzeczywistości, podobnie jak częste u ludzi naiwne traktowanie przywiązania człowieka do zwierzą $\mathrm{t}^{12}$. Zdarza się Mackiewiczowi natomiast, i to nierzadko, sygnalizo-

11 Co nie znaczy, że nie używa tego środka jako stylistycznego ornamentu w swojej prozie (zob. na przykład motto do niniejszego artykułu). Czym innym jest jednak zastosowanie chwytu, który ma głównie funkcje obrazowe związane z plastycznym przedstawieniem natury, a czym innym filozofia stojąca u podstaw światopoglądu pisarza.

"[...] antropomorfizowanie zjawisk w przyrodzie - powiada Mackiewicz - stanowi najbardziej o słabym wyczuciu rzeczywistości. [...] otóż co ludzi interesowało w Krakasiu, to właśnie było coś, co go do nich upodobniało. A to były najbardziej bezmyślne cechy jego kruczego charakteru. - Mnie natomiast zdumiewała w nim celowość jego poczynań. A więc brak wszelkiego 
wać zjawisko odwrotne, czyli "naturalizować” człowieka w celu symbolicznego zasugerowania jego anormalnego odejścia od przyrodzonej mu natury. Taka jest właśnie artystyczna funkcja avisacji cioci Pafci, która sowim „ptasieniem” odsłania sprzeciw wobec wyjątkowej „plastelinowości” ludzkiej natury w wieku XX. „Otóż Krakaś był zawsze sobą" - konstatuje autor, czyniąc tym stwierdzeniem jednoznaczną aluzję do świata współczesnego człowieka, podatnego na myślowe szablony i łatwo zniewalanego przez polityczne doktryny ${ }^{13}$.

\section{5.}

Tego typu znaczenie i funkcja skrzydlatych towarzyszy ludzi nie jest oczywiście odosobniona czy nawet rzadka w pozostałej twórczości Mackiewicza, choć w innych tekstach nie jawi się może w tak spektakularny sposób, jak w przygodach cioci Pafci. Obserwacja i deskrypcja ptaków prowadzi w prozie autora Kontry bardzo często do sugerowania wartości zgodnie ze wskazanym przed chwilą kierunkiem. Dorzućmy na koniec dosłownie tylko garstkę przykładów, które można by mnożyć, przewracając kolejne strony publicystyki i prozy artystycznej pisarza.

Na początek wróćmy na chwilę do wątku autobiograficznego i posłuchajmy, jak komentuje Mackiewicz i własną lekturę przyrodniczą z dzieciństwa, i udane studenckie polowanie na dzięcioła trójpalczastego w Puszczy Białowieskiej:

Dostałem na święta Bożego narodzenia książkę Dyakowskiego Nasz las i jego mieszkańcy. Ciągle jednak natrafiałem w niej na luki i nie mogłem przystosować do mojej spostrzegawczości praktycznej. Zrozumiałem to później. Oto p. Bohdan Dyakowski pisał swą książkę w Warszawie, bardziej dla lewego brzegu Wisły, niż prawego Bugu. Tymczasem nasz las i jego mieszkańcy w zoogeograficznym obszarze Palearktyki należy do typu nie środkowoeuropejskiego a - tajgi...

szablonu. O wieleż wyżej go stawiam od psa! Psa, którego człowiek, właśnie przez antropomorfizowanie zjawisk, wyniósł do Bóg wie jakiej godności akademickiej, nie odróżniając w nim mechanicznej zdolności przystosowania od utraty tych zdolności indywidualnych. Albo pies ma być człowiekiem, albo psem. Otóż Krakaś był zawsze sobą". J. Mackiewicz Krakaś, s. 221.

13 Nieco wcześniej, porównując człowieka i kruka, Mackiewicz zauważył: „[kruk] nie wykala sobie nawzajem oka, jak to wiemy z przysłowia. Człowiek czyni właśnie odwrotnie [...]". Tamże, s. 220. 
Później, w Uniwersytecie Warszawskim, byłem niezmiernie dumny, kiedym dostarczył dla tamtejszego muzeum egzemplarz Picoides triadyctylus z Puszczy Białowieskiej, własnoręcznie ubity. Jest to dzięcioł trójpalczasty, o złocistych piórkach głowy - sensacja! - Jako nieliczny wyjątek, zamieszkujący nasze lasy, bardziej jest zbliżony do gatunku karpackiego, niźli do... syberyjskiego. A więc sensacja przyrodnicza.

Czy można z niej wyciągać wnioski natury politycznej? O, sądzę, że można nawet trawestować na nową syntezę demagogiczną. Ale podchodząc do sprawy spokojnie, odrzucając nawet przykre dla ucha słowo "tajga" - casus Picoides, jako symbol wyjątku, może być zastanawiający dla niektórych metod administrowania naszym krajem. Czy to będzie wywożenie śniegu z ulic Wilna, czy polityka nomadyzmu urzędniczego, płynąca do nas właśnie z Podkarpacia. Czy nie dziwnie się składa, że ptak stamtąd jest wyjątkiem, a urzędnik regułą? ${ }^{14}$

Jesteśmy tu u źródeł Mackiewiczowskiego patriotyzmu pejzażu i całej jego publicystyki interwencyjnej w dwudziestoleciu międzywojennym, publicystyki (z reportażami na czele), w której dominował apel autochtona dawnych ziem wschodnich Rzeczypospolitej o zrozumienie inności tych terenów i poszanowanie specyfiki ich mieszkańców. Przyroda, w tym ptaki, mają w tej kwestii duże znaczenie. Nie tylko w kontekście polityki Warszawy, rzecz jasna. Czasami rozchodzi się o niesnaski narodowościowe, trudne do pojęcia dla Mackiewicza mającego za sobą naukę w rosyjskim Gimnazjum Winogradowa, w którym zgodnie uczyli się Polacy, Rosjanie, Litwini i przedstawicie innych nacji. Oto jak reportażysta komentuje - przy odwołaniu się do symboliki orła - oskarżenia nauczyciela z Wołożyna o rusyfikację i antypaństwową politykę (za to, że ośmielił się powiedzieć przy wejściu do pokoju nauczycielskiego wrogie „Zdrastwujtie dorogije” czy że opuszczał w litanii wezwanie „Mario, Królowo Korony Polskiej”):

Rzec by można, iż cień dwugłowego orła padł na białe skrzydła. Ale orzeł biały spokojnie wisiał nad głową sędziego, odkąd go tam woźny przybił gwoździami. Nie zerwał się, nie przestraszył, nie dziobał na oślep, ujrzawszy cień tylowiekowego swego wroga. Zapewne wyczuł, że ma do czynienia z niebezpieczeństwem urojonym. Stąd wypłynął prosty wniosek, że

14 J. Mackiewicz Syntetycy ziem wschodnich, "Słowo” 1938 nr 14, w: tegoż Okna zatkane szmatami, S. $253-254$. 
orły mądrzejsze są od ludzi, a może tylko obdarzone zdrowym instynktem, którego Bóg ludziom poskąpił. ${ }^{15}$

Równie mocno znaczenie symboliczne ptaków wybrzmiewa, gdy mowa o dużo poważniejszym zagrożeniu dla autonomii ziem byłego Wielkiego Księstwa Litewskiego. Oto jak przedstawione są pliszki na granicy między Rzeczpospolitą i Związkiem Sowieckim po traktacie ryskim:

Po obu stronach rzeki stoją słupy. Obydwa jednakie i objętością, i wzrostem, na jednakich kopcach, patrzą ku sobie twarzami tablic: Orzeł i Rzeczpospolita Polska; Sierp z młotem i na górze SSSR, u dołu BSSSR. Cyfry też są te same. - Na słup 483 lecą żółte polne pliszki. Samiec usiadł na polskim, samiczka przeleciała parę metrów, siadła na sowiecki. Machają ogonkami, jak to we zwyczaju pliszek bywa, i ćwierkają ku sobie miłośnie. Nad granicą świeci słońce. ${ }^{16}$

Tego typu przeciwstawień zachowań natury i człowieka, w którym główną rolę odgrywają ptaki, jest w prozie Mackiewicza dużo więcej. Warto zauważyć przy tym, że pisarz celowo sugeruje ich symboliczną funkcję. Oprócz pytania retorycznego dotyczącego kołchoźnika i ułasnika z obu stron granicy: „który z nich jest wolny?”, pojawia się refleksja: „Wolny jest ptak, który leci het, wysoko, który zatacza kręgi nad łąką i rzeką i granicy nijakiej nie widzi"17. Czasami chciałoby się nawet, żeby sugestie pisarza w tym względzie były może nieco mniej dosadne i obcesowe:

Z tej na tamtą stronę poleciały bociany. Są one i białe, jak my, i czerwone mają dzioby, jak bolszewicy. Im dobrze tu i dobrze tam. Byle łąka i żaby. I nikt nie uznaje tu granicy, ani trawa, ani rzeka, ani las, ani ptaki, ani zwierzęta. Tylko ci ludzie, którzy zasiedli w dalekiej Rydze do stołu konferencyjnego. ${ }^{18}$

15 J. Mackiewicz Ty wiesz, że dumni nieszczęściem nie moga za innych śladem iść tamta drogq̨..., "Słowo" 1936 nr 151 (3 czerwca), w: Bulbin z jednosielca, s. 421. Tytuł artykułu jest cytatem z Wacława Juliusza Słowackiego.

16 J. Mackiewicz Słońce świeci nad granicq, "Słowo” 1935 nr 194 (18 lipca), w: tegoż Bulbin z jednosielca, s. 344 .

17 Tamże, s. 346.

18 Tamże, s. 351. 
Zestawienie ptaków i ludzi powraca także w fabułach literackich Mackiewicza. Poza najbardziej spektakularną w tym względzie ciocią Pafcią warto szerzej przypomnieć postać ptasznika z Drogi donikąd, będącego w istocie czytelnym porte-parole autora powieści. Jego biografia łącząca w sobie element rosyjski (urodzony nad Wołgą) i polski, prawosławie (żona) i katolicyzm, jego ucieczka przed komunizmem na zachód po dojściu Lenina do władzy, a także fascynacja ptakami - to wszystko bardzo przypomina rodowód i profil osobowy autora Kontry. Kluczowa jednak dla powieści i identyfikacji postaci jako medium autorskiego światopoglądu jest rozmowa ptasznika, w której tłumaczy on głównemu bohaterowi powieści, Pawłowi, różnice między ptakami a ludźmi:

Ja nie uczony, ale powiem panu, że ludzie nawet uczeni, a nie zawsze pojmują. Kiedy mówią: ptaszki. U nich i dzięcioł ptaszek, i sikorka, i drozd, i kanarek ptaszek. Że ptaszek, to prawda, ale każdy innego gatunku. A my, ludzie, im naprzeciw, to też tylko gatunek jeden i ten sam, a nie żeby kilka. - Są jednak różnice między narodami.

- Są, nie będę się spierał, ale tylko z wychowania czy obyczajów, a nie z gatunku. Czy to będzie jaki tam Hiszpan czy Ruski, czy Francuz, czy Niemiec, to wszyscy, jakby powiedzieć: tylko szczygieł czy tylko sikorka. I nie tak jak różne sikorki, jeden naród, na przykład: bogatki, drugi: czarnogłówki, a trzeci: czubatki. Nie, wszystkie to samo, na przykład: czarnogłówki. A zwyczaje, ma się rozumieć, różne mogą być. Gil na przykład na swobodzie je zwyczajnie jarzębinę, a w klatce woli konopie. Znaczy, zwyczaj swój zmienia. Ale różnica gatunku w czym innym objawia się. Widzisz pan tę klatkę, do połowy chustką zawiniętą? Ja w niej próbuję połączyć samca czyża z samką kanarka. W nauce, to one uchodzą, jakby powiedzieć, za najbliższych krewnych, z jednego pnia, jednej rodziny. A zobacz pan, ile sztuki trzeba, ile zachodu, ile różności i jakiego doboru, a jeszcze rzadko udaje się doprowadzić, żeby czyż pokrył samkę kanarka. W dodatku jajka wychodzą najczęściej puste. Tymczasem uczeni nazywają, że oni są bliskie, a między narodami, to tylko i szukają różnicy i ciągle wywodza, że jeden od drugiego daleki. A za przeproszeniem pana [...], żeby pokryć Polaka z Niemką, czy jakiego Francuza z Ruską, to żadnych do tego sztuk nie trzeba... I dzieci jeszcze rodzą się, bywa, zdrowsze. A dlaczego? Bo my wszyscy, kość z kości, krew z krwi te same... I nawet Żydzi, choć Chrystusa zamordowali, też te same ${ }^{19}$.

19 J. Mackiewicz Droga donikq̨d, Wydawnictwo Kontra, Londyn 1989, s. 213. 
Jak wyraźnie widać, ptaki są dla Mackiewicza grupą zwierząt, która wspólnie z niektórymi innymi elementami natury dzieli w jego świecie przedstawionym funkcje wskazywania na świat wartości podstawowych. Trudno o lepszą niż dialog powyższy egzemplifikację wykładu antropologii fizycznej czy naturalnej, której Mackiewicz był wyznawcą ${ }^{20}$. Odchodzenie od jej praw, zdaniem pisarza, prowadzi bezpośrednio do zafałszowania przez człowieka własnej natury. Wydaje się, że skrzydlaci towarzysze człowieka są w tym aspekcie szczególnie istotną i uprzywilejowaną częścią przyrody. Obserwacja zarówno przywołanych, jak i wielu innych przykładów, których nie jestem tu ze względu na brak miejsca szerzej rozpatrzyćc1 ${ }^{21}$ ogólna częstotliwość występowania ptaków w odmiennych, niemetaforycznych znaczeniach, a także pietyzm ich opisywania pozwalają sądzić, że stanowią one wyróżnioną funkcjonalnie część natury w świecie artystycznym prozy Mackiewicza. Niestety w I połowie XX wieku, którą przedstawia w swoich tekstach pisarz, nie tylko Słowiańszczyzna (zwłaszcza wschodnia) czy Europa, ale człowiek w ogólności, wygląda z ich perspektywy nieciekawie. A dlaczego? Bo trawa pozostaje trawą, rzeka - rzeką, las - lasem, ptak - ptakiem. Tylko ludzie stają się dziwni, nieludzcy, choć Mackiewicz z pewnością nie powiedziałby, że nastąpiło ich „zezwierzęcenie". Wręcz przeciwnie, u niego avisacja i inne animizacje człowieka sygnalizują raczej opowiedzenie się po stronie prawdy przyrodzonej i zasadniczy sprzeciw wobec szerzącego się w XX wieku „ludzkiego potwora"22.

Do tego typu antropologii odwołuje się Mackiewicz wielokrotnie, a najbardziej wprost czyni to w szkicu Zgoda 6 czyli pęk kluczy, "Wiadomości" 1971 nr 40, w: tegoż Fakty, przyroda i ludzie, przedm. B. Toporska, Wydawnictwo Kontra, Londyn 1984, s. 303.

21 Na osobną uwagę zasługuje na przykład rola ptaków i innych aspektów przyrody w kształtowaniu się kryteriów wartościowania w krytykach literackich Mackiewicza. Tytułem przykładu przywołuję jeden tylko fragment z tego typu wypowiedzi, poświęcony pisarstwu Michała Kryspina Pawlikowskiego: „Osobiście mam największe zaufanie do «naturalistów». Wydaje mi się zawsze, że łatwiej chwytają związki przyczynowe jakie są, w odróżnieniu od innych, którzy wolą je dostrzegać jakimi być powinny. Ten swoisty naturalizm w widzeniu rzeczy Pawlikowski przenosił z głuszców i cietrzewi na ludzi”. J. Mackiewicz Michał K. Pawlikowski, „Wiadomości" 1972 nr 34, w: J. Mackiewicz, B. Toporska Droga Pani..., Wydawnictwo Kontra, Londyn 2012, s. 467.

Określeniem tym nazwał pisarz ratujących się przed śmiercią i chowających po lasach Żydów, ale odnieść je można - jak sądzę - także do kondycji oprawców. Z tym że ci ostatni zdolni są do "potwornych" czynów, które z kolei prowadzą do „potwornych" zmian w ich ofiarach, a także w ludziach towarzyszących takim zdarzeniom. Faktograficzne, ale i zarazem paraboliczne arcydzieło literatury faktu na ten temat, które wyszło spod pióra Mackiewicza, to niezwykły 


\section{Abstract}

\section{Adam Fitas}

THE JOHN PAUL II CATHOLIC UNIVERSITY OF LUBLIN

\section{Birds in Józef Mackiewicz's Works}

Józef Mackiewicz's representations of nature frequently include birds, which play a variety of artistic roles. Fitas discusses the most memorable instances of this key motif by exploring Mackiewicz's journalistic and novelistic works, in particular his novella Faux-pas ciotki Pafci [Auntie Pafcia's Faux-pas]. Birds appear as a clear pars pro toto of nature, and they point to the tension between the natural and the human in the real twentiethcentury world, dominated as it is by politics and ideology. Although this article is based on a traditional structural methodology, Fitas concludes by suggesting ways in which it could offer a point of departure for future studies based on modern methodologies (e.g. ecocriticism, the natural and the human in Walter Benjamin or Giorgo Agamben).

\section{Keywords}

Józef Mackiewicz, birds, nature, human, ideology

reportaż o zagładzie Żydów w podwileńskich Ponarach. Zob. J. Mackiewicz Ponary - „Baza”, "Orzeł Biały" 1945 nr 35, w: Fakty, przyroda i ludzie, s. 17-25. Cały sygnalizowany w moim szkicu problem relacji człowieka do przyrody, choć już mający w mackiewiczologii literaturę przedmiotu, z pewnością jest interesującym materiałem dla rozwijania różnych współczesnych kontekstów metodologicznych związanych z tymi problemami. Wydaje się na przykład, że ciekawe byłoby pokazanie autora Kontry, o czym wspominał w swojej monografii już Bolecki, jako swoistego i oczywiście nieświadomego pioniera ekokrytyki w Polsce, a także skonfrontowanie jego widzenia natury z refleksją na temat różnicy między tym, co ludzkie i tym, co zwierzęce we współczesnych debatach filozoficznych, na przykład w refleksji Giorgio Agambena. Jestem pewien, że wcześniej czy później te ścieżki refleksji zostaną przez badaczy podjęte z korzyścią dla interpretacji twórczości pisarza. 